\title{
Nocardioides exalbidus sp. nov., a novel actinomycete isolated from lichen in Izu-Oshima Island, Japan
}

\author{
Bing $\mathrm{Li}^{*}$, Cheng-Hui Xie and Akira Yokota \\ Institute of Molecular and Cellular Biosciences, The University of Tokyo, \\ Yayoi 1-1-1, Bunkyo-ku, Tokyo 113-0032, Japan \\ (Received Nov. 6, 2006 / Accepted Jan. 11, 2007 / Published May 18, 2007)
}

\begin{abstract}
A short coccoid- or rod-shaped, non-motile actinomycete strain $\mathrm{RC}^{-25}{ }^{\mathrm{T}}$ was isolated from lichen in IzuOshima Island, Japan. A polyphasic study was undertaken to establish the taxonomic position of this strain. Phylogenetic analysis based on $16 \mathrm{~S}$ rRNA gene sequence revealed that strain $\mathrm{RC}^{2} 5^{\mathrm{T}}$ forms an evolutionary lineage within the radiation of the genus Nocardioides. In particular, it forms a coherent cluster with Nocardioides oleivorans and Nocardioides ganghwensis with high sequence similarity of 98 and $97.5 \%$, respectively. However, DNA-DNA hybridization experiment demonstrated that strain $\mathbf{R C}^{825}{ }^{\mathrm{T}}$ is distinct from its closest phylogenetic neighbors, $N$. oleivorans and $N$. ganghwensis, with 44 and $39 \%$ relatedness, respectively. The cell-wall peptidoglycan of strain $\mathrm{RC}{ }^{-\mathrm{T}}$ contained LL-diaminopimelic acid, indicating wall chemotype I. The predominant menaquinone was $\mathrm{MK}-8\left(\mathrm{H}_{4}\right)$. Strain $\mathrm{RC}^{2} \mathrm{~S}^{\mathrm{T}}$ had a cellular fatty acid profile containing straight-chain, branched, unsaturated and 10-methyl fatty acids, and the major fatty acid was iso- $\mathrm{C}_{16: 0}$. The DNA $\mathrm{G}+\mathrm{C}$ content of the strain was $74 \mathrm{~mol} \%$. On the basis of both phenotypic and phylogenetic evidence, the strain is separated from previously described Nocardioides species, and should be assigned to represent a novel species of the genus Nocardioides, for which the name Nocardioides exalbidus sp. nov. is proposed. The type strain is strain $\operatorname{RC825}^{\mathrm{T}}\left(=\mathrm{IAM} 15416^{\mathrm{T}}=\mathrm{CCTCC}^{\mathrm{AA206016}}{ }^{\mathrm{T}}\right.$ ).
\end{abstract}

\section{INTRODUCTION}

The genus Nocardioides was proposed by Prauser ${ }^{1)}$ for nocardioform actinomycetes that form mycelium fragments into irregular rod to coccus-like elements. The organisms are Gram-positive, non-acid-fast, aerobic and mesophilic, and have a cell wall based on LL-diaminopimelic acid, the diagnostic diamino acid of wall chemotype $\mathrm{I}^{1)}$. At the time of writing, the genus Nocardioides was composed of 26 species with validly published names, including the recently described species $N$. kongjuensis ${ }^{2}, N$. lentus $^{3)}, N$. kribbensis $^{4)}$, and $N$. oleivorans ${ }^{5}$. The aim of the present study was to determine the taxonomic position of isolate $\mathrm{RC} 825^{\mathrm{T}}$ using a combined polyphasic taxonomic approach. Based on the physiological properties, chemotaxonomic characteristics, and phylogenetic analysis, we propose that the isolate should be placed in the genus Nocardioides as a new species.

\section{MATERIALS AND METHODS}

During the course of the isolation of diazotrophs, strain $\mathrm{RC} 825^{\mathrm{T}}$ was isolated from lichen in Izu-Oshima Island, Japan, by plating it directly on IAM-A1 agar medium as follows: the lichen sample was washed five times with sterilized water, and subsequently crushed in $1 \mathrm{ml}$ of sterilized water. The effluent was streaked on IAM-A1 agar medium. After 2 weeks of incubation, white colonies developed on the medium were re-streaked and purified on Trypticase soy agar (TSA; BBL) and maintained on the same agar slant at $4{ }^{\circ} \mathrm{C}$, and as a glycerol suspension $(10 \%$, $\mathrm{v} / \mathrm{v})$ at $-80^{\circ} \mathrm{C}$. The cell morphology was observed by light microscopy (BX60; Olympus). For phenotypic properties, the growth range for temperature and $\mathrm{pH}$ were tested on TSA medium. Catalase activity was determined by bubble production in a $3 \%$ hydrogen peroxide solution. Oxidase was determined by cytochrome oxidase paper (Nissui Pharmaceutical). Salinity tolerance was determined by inoculating the strain into ISP2 (Difco) medium supplemented with $0-12 \%(\mathrm{w} / \mathrm{v}) \mathrm{NaCl}$ at $1 \%$ increments. API $50 \mathrm{CH}, 20 \mathrm{E}$, API ZYM strips (bioMérieux) were used according to the manufacturer's instructions to determine all physiological and biochemical characteristics of the strains.

Freeze-dried cells for chemotaxonomic studies were obtained upon incubation of the organism in trypticase soy broth (TSB; BBL) medium on a rotary shaker at $160 \mathrm{rpm}$ at $27^{\circ} \mathrm{C}$ for 4 days. For cellular fatty acid analysis, the strain was grown on TSA (BBL) at $27^{\circ} \mathrm{C}$ for 3 days, and fatty acid methyl esters were prepared and identified using the

\footnotetext{
${ }^{*}$ Corresponding author. E-mail: aa67047@mail.ecc.u-tokyo.ac.jp

The GenBank/EMBL/DDBJ accession number for the 16S rRNA gene sequence of strain $\mathrm{RC}^{2} 5^{\mathrm{T}}$ is $\mathrm{AB} 273624$ (=IAM $15416^{\mathrm{T}}=\mathrm{CCTCC}^{\mathrm{AA} 206016^{\mathrm{T}}}$ ).
} 
Microbial Identification System as described by Xie and Yokota $^{6}$. Amino acid composition and isomers of diaminopimelic acid (DAP) in the cell walls were examined by two-dimensional TLC (Tokyo Kasei Co., Ltd., Tokyo, Japan) as described by Harper and Davis ${ }^{7)}$ and by HPLC according to the procedures of Yokota et al. ${ }^{8}$. Phospholipids were extracted and identified using two-dimensional TLC, followed by spraying with appropriate detection reagents according to the method of Yokota et al. ${ }^{9}$. Respiratory quinone was extracted and analyzed by the method of Komagata and Suzuki ${ }^{10)}$.

DNA was prepared according to the method of Marmur ${ }^{11)}$ from cells grown on TSB medium, and the $\mathrm{G}+\mathrm{C}$ content of DNA was determined using the HPLC method of Mesbah et al. ${ }^{12)}$. An approximately 1500 -bp fragment of the 16S rRNA gene was amplified from extracted DNA using bacterial universal primers specific to the $16 \mathrm{~S}$ rRNA gene, primer 8F, 5'-AGAGTTTGATCCTGGCTCAG-3' (positions 8-27, according to the Escherichia coli numbering system of Brosius et al. ${ }^{13)}$ ), and primer 1510R, $5^{\prime}$ GGCTACCTTGTTACGTA-3' (positions 1510-1527). PCR products were purified by the PEG precipitation method ${ }^{14)}$. Amplicons were directly sequenced using the BigDye Terminator v1.1 Cycle Sequencing kit (Applied Biosystems). We compared the 16S rRNA gene sequence of $\mathrm{RC} 825^{\mathrm{T}}$ with sequences obtained from GenBank (National Center for Biotechnology Information). These sequences were aligned with the CLUSTAL X software package ${ }^{15)}$, and evolutionary distances and the Knuc value ${ }^{16)}$ were generated. Alignment gaps and ambiguous bases were not taken into consideration in the calculations. A phylogenetic tree based on a comparison of 1336 bases was constructed using the neighbor-joining method ${ }^{17)}$. The topology of the tree was evaluated using the bootstrap resampling method of Felsenstein ${ }^{18)}$ with 1000 replicates, whereas similarity values were calculated using MEGA $3^{19)}$. DNA-DNA hybridization was performed by photobiotin-labelled probes in microplate wells as described by Ezaki et al. ${ }^{20)}$, using a multi-well plate reader (CytoFluoR; PerSeptive Biosystems).

\section{RESULTS AND DISCUSSION}

The morphological and chemotaxonomic characteristics of strain $\mathrm{RC} 825^{\mathrm{T}}$ are consistent with its assignment to the genus Nocardioides. The cells are Gram-positive, nonendospore-forming, non-motile, irregular coccoid- to rodshaped, and about $0.5 \mu \mathrm{m}$ wide and up to $2.0 \mu \mathrm{m}$ long. Substrate or aerial mycelia were not observed (Fig. 1). The strain is positive for catalase activity and negative for oxidase activity. Growth occurs at $15-35^{\circ} \mathrm{C}, \mathrm{pH} 6-9$, with the optimum being at $30^{\circ} \mathrm{C}$ and $\mathrm{pH}$ 7. The results of API $50 \mathrm{CH}, 20 \mathrm{E}$ and API ZYM kits and carbon source utilization are given in Table 1 .

Chemotaxonomic characteristics: cell wall analysis by HPLC and TLC indicated that the strain contained LL-

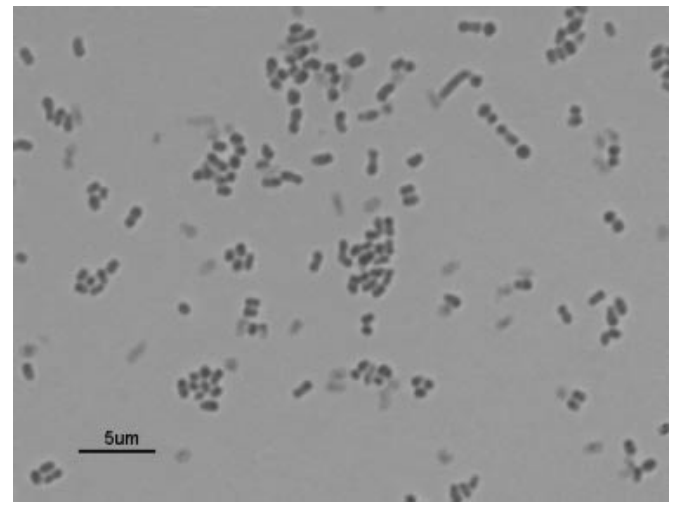

Fig. 1. Light micrograph of strain $\mathrm{RC} 825^{\mathrm{T}}$ cells grown on ISP2 agar medium for $48 \mathrm{~h}$ at $30^{\circ} \mathrm{C}$.

DAP in cell wall peptidoglycan, characteristic of cell wall chemotype I sensu Lechevalier \& Lechevalier ${ }^{21)}$. The predominant menaquinone was MK-8( $\left.\mathrm{H}_{4}\right)$. Diphosphatidylglycerol and phosphatidylinositol were present as major polar lipids, but no phosphatidylcholine was found. The DNA G+C content of the strain was $74 \mathrm{~mol} \%$. The major fatty acids were iso- $\mathrm{C}_{16: 0}$ and 10-methyl branched fatty acids, which are characteristically found as major components in the genus Nocardioides ${ }^{22}$. The strain also had relatively high proportions of iso- $\mathrm{C}_{17: 0}$ and anteiso- $\mathrm{C}_{17: 0}$ (Table 2).

Phylogenetic analysis: an almost complete 16S rRNA gene sequence (1453 nt) of $\mathrm{RC} 825^{\mathrm{T}}$ was determined and has been deposited in the DDBJ database. Phylogenetic analysis of the 16S rRNA gene sequence revealed that the isolate fell within the genus Nocardioides (Fig. 2) with 99\% bootstrap support. To ascertain the phylogenetic position of strain $\mathrm{RC} 825^{\mathrm{T}}$, we aligned its $16 \mathrm{~S}$ rRNA gene sequence (1336 nt) with those of type strains of species of the genus Nocardioides. The strain showed the highest similarities to the sequences of $N$. oleivorans IAM $15341^{\mathrm{T}}$ $(98 \%)$ and $N$. ganghwensis IAM $15306^{\mathrm{T}}$ (97.5\%). However, a DNA-DNA hybridization experiment demonstrated that the strain was distinct from $N$. oleivorans IAM $15341^{\mathrm{T}}$ and $N$. ganghwensis IAM $15306^{\mathrm{T}}$ with $44 \%$ and $39 \%$ relatedness, respectively, which were well below the $70 \%$ cut-off point recommended for the delineation of bacterial species ${ }^{23}$. These results indicate that strain $\mathrm{RC} 825^{\mathrm{T}}$ represents a separate species in the genus Nocardioides.

Strain $\mathrm{RC} 825^{\mathrm{T}}$ could also be distinguished from other species of the genus Nocardioides by different physiological and biochemical characteristics of this new isolate as shown in Tables 1 and 2. In particular, strain $\mathrm{RC} 825^{\mathrm{T}}$ differed from the phylogenetically closest species $N$. ganghwensis and $N$. oleivorans in terms of utilization of D-cellobiose, D-galactose and $N$-acetyl-glucosamine as well as the activity of naphthol-AS-BI-phosphohydrolase. Other characteristics such as citrate utilization, activity of arginine dihydrolase, tryptophan deaminase, lysine decar- 
Table 1. Characteristics that distinguish strain $\mathrm{RC} 825^{\mathrm{T}}$ from the closely related species of the genus Nocardioides strains: 1 , strain RC825 $;$; 2, N. ganghwensis; 3, N. oleivorans; 4, N. albus; 5, N. aquaticus; 6, N. aquiterrae; 7, N. jensenii; 8, N. luteus; 9, N. nitrophenolicus; $10, N$. plantarum; $11, N$. pyridinolyticus; $12, N$. simplex. Characteristics are scored as follows: + , Positive reaction; -, negative reaction; W, weakly positive; V, variable. All Nocardioides strains are positive for Gram reaction, catalase, esterase lipase (C8) and leucine arylamidase; negative for $N$-acetyl- $\beta$-glucosaminidase, $\beta$-glucuronidase and $\alpha$-fucosidase. Data are from Schippers $e t$ $a l .{ }^{5)}$, Yi \& Chun ${ }^{24)}$ and Yoon et $a_{l}{ }^{3)}$.

\begin{tabular}{|c|c|c|c|c|c|c|c|c|c|c|c|c|}
\hline Characteristic & 1 & 2 & 3 & 4 & 5 & 6 & 7 & 8 & 9 & 10 & 11 & 12 \\
\hline Motility & - & - & - & - & - & + & - & - & + & - & + & + \\
\hline Mycelium and spore formation & - & - & - & + & - & - & - & + & - & - & - & - \\
\hline Nitrate reduction & - & + & ND & - & + & + & + & - & - & - & + & - \\
\hline Urease & - & - & ND & - & - & - & + & - & - & - & - & - \\
\hline Hydrolysis of aesculin & - & $\mathrm{W}$ & ND & $\mathrm{W}$ & - & + & - & + & $\mathrm{W}$ & $\mathrm{W}$ & + & + \\
\hline Hydrolysis of starch & - & + & ND & + & - & + & - & + & - & - & + & $\mathrm{W}$ \\
\hline \multicolumn{13}{|l|}{ Carbon source utilization: } \\
\hline Citrate & - & + & - & + & - & W & + & + & + & + & - & + \\
\hline D-Cellobiose & - & + & + & + & - & + & - & + & - & + & + & - \\
\hline D-Fructose & + & + & + & + & + & + & - & - & + & + & + & - \\
\hline D-Galactose & - & + & + & + & + & + & - & - & - & - & + & - \\
\hline D-Glucose & + & + & + & + & + & + & + & + & + & - & + & + \\
\hline D-Mannitol & + & + & + & + & + & + & - & + & - & - & - & - \\
\hline D-Mannose & - & + & + & + & - & - & - & + & - & - & - & - \\
\hline D-Raffinose & - & + & ND & - & - & - & - & - & - & - & - & - \\
\hline D-Ribose & - & - & - & - & - & - & - & - & + & - & + & - \\
\hline D-Salicin & - & + & - & $\mathrm{W}$ & - & - & - & - & - & + & - & - \\
\hline D-Xylose & - & + & - & + & + & + & - & + & + & + & + & - \\
\hline Glycerol & - & + & ND & $\mathrm{W}$ & + & - & W & - & - & + & - & - \\
\hline Inositol & - & - & - & - & - & - & - & - & - & - & + & - \\
\hline Lactose & - & + & ND & - & - & - & - & - & - & - & - & - \\
\hline L-Arabinose & - & + & - & + & - & - & - & + & - & - & - & - \\
\hline L-Rhamnose & + & - & + & + & W & - & + & - & + & + & + & - \\
\hline$N$-Acetyl-glucosamine & - & + & + & $\mathrm{W}$ & - & - & - & + & - & - & - & - \\
\hline Sucrose & + & + & + & - & + & + & $\mathrm{W}$ & - & + & + & + & + \\
\hline \multicolumn{13}{|l|}{ API ZYM: } \\
\hline Alkaline phosphatase & + & + & + & + & $\mathrm{V}$ & - & $\mathrm{W}$ & $\mathrm{V}$ & + & - & + & + \\
\hline Esterase (C4) & $\mathrm{W}$ & $\mathrm{V}$ & - & + & W & - & W & + & - & + & - & - \\
\hline Lipase (C4) & - & - & - & - & - & - & - & - & - & $\mathrm{W}$ & - & - \\
\hline Valine arylamidase & + & + & + & - & $\mathrm{W}$ & - & $\mathrm{V}$ & - & + & $\mathrm{W}$ & $\mathrm{W}$ & $\mathrm{W}$ \\
\hline Cystine arylamidase & $\mathrm{W}$ & $\mathrm{W}$ & $\mathrm{W}$ & - & $\mathrm{V}$ & $\mathrm{W}$ & - & - & $\mathrm{W}$ & + & - & $\mathrm{W}$ \\
\hline Trypsin & - & - & - & + & $\mathrm{W}$ & + & $\mathrm{W}$ & + & + & - & + & + \\
\hline Acid phosphatase & W & W & - & - & + & + & $\mathrm{V}$ & - & + & $\mathrm{W}$ & + & W \\
\hline Naphthol-AS-BI-phosphohydrolase & + & - & $\mathrm{W}$ & $\mathrm{W}$ & - & + & $\mathrm{V}$ & $\mathrm{V}$ & + & + & + & - \\
\hline$\alpha$-Galactosidase & + & + & $\mathrm{W}$ & - & - & - & - & - & - & - & - & - \\
\hline$\beta$-Galactosidase & + & + & + & $\mathrm{V}$ & - & - & - & $\mathrm{V}$ & - & - & - & - \\
\hline$\alpha$-Glucosidase & + & + & + & + & + & + & $\mathrm{V}$ & $\mathrm{V}$ & + & + & + & + \\
\hline$\beta$-Glucosidase & $\mathrm{W}$ & - & - & $\mathrm{W}$ & - & W & - & - & $\mathrm{W}$ & + & - & W \\
\hline$\alpha$-Mannosidase & - & - & - & - & - & - & - & + & - & - & - & - \\
\hline
\end{tabular}

boxylase, and ornithine decarboxylase, production of hydrogen sulfide and indole, and Voges-Proskauer test are negative. Positive results are for the activity of $o$-nitrophenyl- $\beta$-D-galactosidase (ONPG) and gelatin hydrolysis. On the basis of phenotypic, chemotaxonomic, and phylogenetic characteristics, we propose that strain $\mathrm{RC} 825^{\mathrm{T}}$ be assigned to the genus Nocardioides as Nocardioides exalbidus sp. nov.

\section{DESCRIPTION OF NOCARDIOIDES EXALBIDUS SP. NOV.}

Nocardioides exalbidus ([ex.al.bi'dus]. L. adj. exalbidus whitish, i.e., white-colored).

The cells are Gram-positive, non-endospore-forming, non-motile, irregular rods of about $0.5 \mu \mathrm{m}$ wide and up to $2.0 \mu \mathrm{m}$ long. Grows well over a $\mathrm{pH}$ range of $6.0-9.0$ on 
Table 2. Whole-cell fatty acid composition (\%) of strain $\mathrm{RC} 825^{\mathrm{T}}(1)$ and of the phylogenetically closest related type strains $N$. ganghwensis IAM $15306^{\mathrm{T}}(2)$ and $N$. oleivorans IAM $15341^{\mathrm{T}}(3)$. Data were taken from Yi \& Chun $^{24)}$, Schippers et $a l .{ }^{5)}$ and this study.

\begin{tabular}{lrrr}
\hline Fatty acids & $\mathbf{1}$ & $\mathbf{2}$ & $\mathbf{3}$ \\
\hline Saturated fatty acids & & & \\
$\mathrm{C}_{17: 0}$ & 1.8 & 1.1 & 2.1 \\
$\mathrm{C}_{18: 0}$ & 5.8 & 7.5 & 0.2 \\
Unsaturated fatty acids & & & \\
$\mathrm{C}_{17: 1 \omega 6 \mathrm{c}}$ & 4.7 & 5.7 & 1.6 \\
$\mathrm{C}_{17: 1 \omega 8 \mathrm{c}}$ & 1.3 & 2.2 & 25.7 \\
$\mathrm{C}_{18: 1 \omega \mathrm{c}}$ & 6.0 & 27.5 & 5.7 \\
Branched fatty acids & & & \\
iso- $\mathrm{C}_{15: 0}$ & 1.4 & 2.3 & 2.7 \\
iso- $\mathrm{C}_{16: 0}$ & 28.0 & 18.6 & 30.4 \\
iso- $_{17: 0}$ & 9.1 & 6.6 & 2.4 \\
iso- $_{17: 1 \omega 9 \mathrm{c}}$ & 2.2 & 2.0 & 1.6 \\
anteiso- $\mathrm{C}_{17: 0}$ & 6.9 & 4.7 & 0.6 \\
iso- $_{18: 0}$ & 5.3 & 1.8 & 1.2 \\
10-methyl-fatty acids & & & \\
$\mathrm{C}_{17: 0}$ & 7.7 & 3.1 & 3.9 \\
$\mathrm{C}_{18: 0}$ & 18.2 & 9.0 & 0.2 \\
\hline
\end{tabular}

TSA medium; the optimal $\mathrm{pH}$ for growth is around 7.0. The temperature of growth was $15-35^{\circ} \mathrm{C}$; the optimal temperature for growth is $30^{\circ} \mathrm{C}$. Catalase activity is positive, whereas oxidase activity is negative. Positive results were recorded for the activity of alkaline phosphatase, leucine arylamidase, valine arylamidase, cystine arylamidase, acid phosphatase, naphthol-AS-BI-phosphohydrolase, $\alpha$-galactosidase, $\alpha$-glucosidase, and $\beta$-glucosidase. The strain utilizes D-glucose, L-rhamnose, D-mannitol, amygdalin, melibiose, 2-keto-gluconate, and 5-keto-gluconate as sole carbon and energy sources. Glycerol, erythritol, L-arabinose, $\mathrm{D}$-xylose, adonitol, methyl $\beta$-D-xyloside, D-galactose, Dmannose, sorbose, dulcitol, methyl $\alpha$-D-mannoside, methyl $\alpha$-D-glucoside, $N$-acetyl-glucosamine, arbutin, D-cellobiose, maltose, lactose, trehalose, sorbitol, inulin, melezitose, D-raffinose, starch, glycogen, gentiobiose, xylitol, Darabitol, gluconate, D-turanose, D-lyxose, D-tagatose, and L-arabitol are not utilized. Diamino acid in the peptidoglycan is LL-diaminopimelic acid (wall type I). The predominant menaquinone was $\mathrm{MK}-8\left(\mathrm{H}_{4}\right)$. Diphosphatidylglycerol and phosphatidylinositol were present as major polar lipids, but no phosphatidylcholine was found. The predominant fatty acids were iso- $\mathrm{C}_{16: 0}, 10$-methyl $\mathrm{C}_{18: 0}, 10$ -

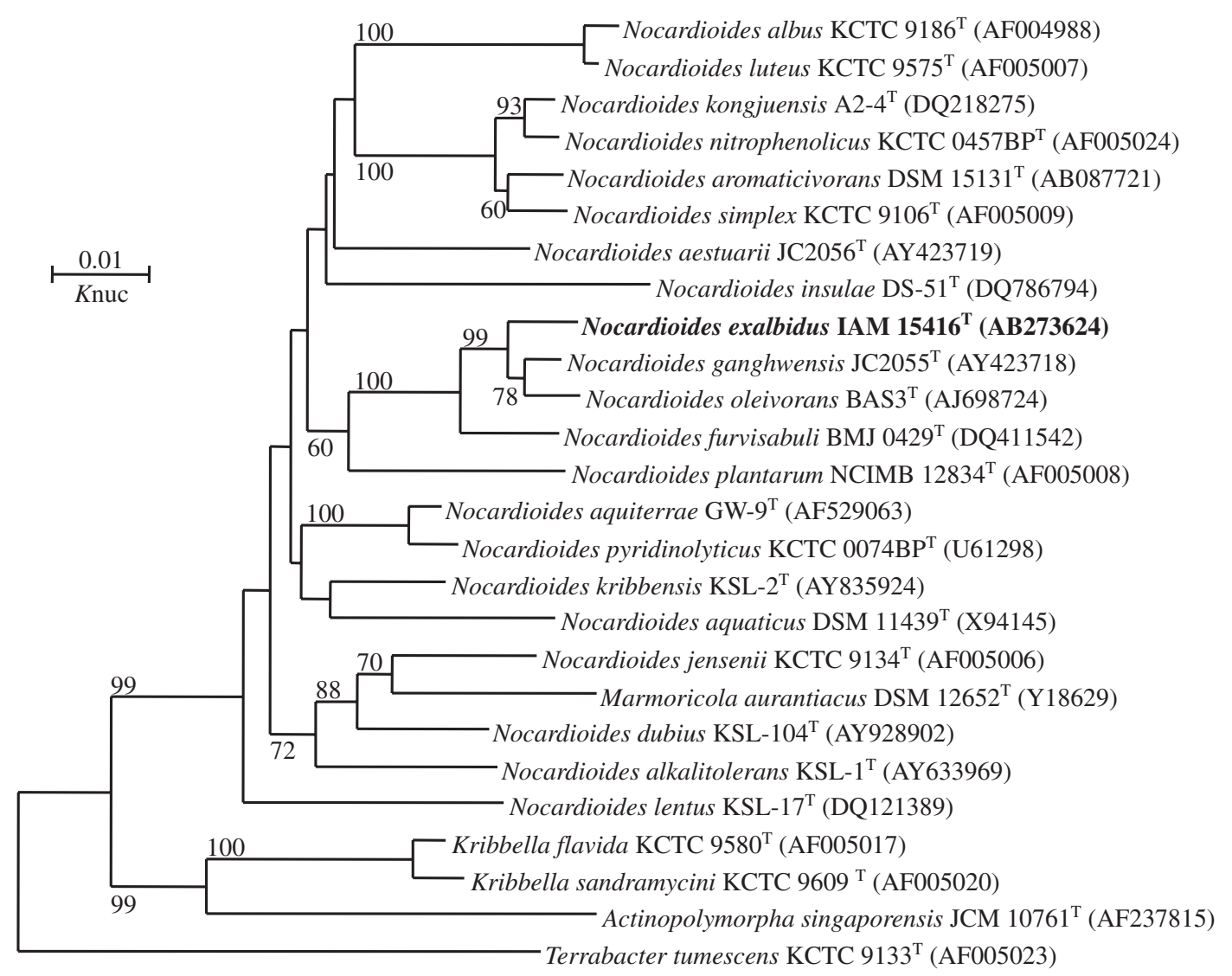

Fig. 2. The 16S rRNA gene sequence phylogenetic tree generated using the neighbor-joining method shows relationships between strain $\mathrm{RC} 825^{\mathrm{T}}$ and representatives of the genus Nocardioides. Numbers at the nodes indicate percentages of occurrence in 1000 bootstrapped trees; only values greater than $50 \%$ are shown. 
methyl $\mathrm{C}_{17: 0}$, iso- $\mathrm{C}_{17: 0}$ and anteiso- $\mathrm{C}_{17: 0}$. The DNA $\mathrm{G}+\mathrm{C}$ content of the strain was $74 \mathrm{~mol} \%$.

The type strain, strain RC $825^{\mathrm{T}}$ (=IAM $15416^{\mathrm{T}}=\mathrm{CCTCC}$ AA206016 ${ }^{\mathrm{T}}$ ), was isolated from the lichen in Izu-Oshima Island, Japan.

\section{REFERENCES}

1) Prauser, H.: Nocardioides, a new genus of the order Actinomycetales. Int. J. Syst. Bacteriol. 26: 58-65, 1976

2) Yoon, J.-H.: J.-K. Lee, S.-Y. Jung, J.-A. Kim, H.-K. Kim \& T.-K. Oh: Nocardioides kongjuensis sp. nov., an $\mathrm{N}$-acylhomoserine lactone-degrading bacterium. Int. J. Syst. Evol. Microbiol. 56: 1783-1787, 2006

3) Yoon, J.-H.: C.-H. Lee \& T.-K. Oh: Nocardioides lentus sp. nov., isolated from an alkaline soil. Int. J. Syst. Evol. Microbiol. 56: 271-275, 2006

4) Yoon, J.-H.: I.-G. Kim, M.-H. Lee \& T.-K. Oh: Nocardioides kribbensis sp. nov., isolated from an alkaline soil. Int. J. Syst. Evol. Microbiol. 55: 1611-1614, 2005

5) Schippers, A.: P. Schumann \& C. Spröer: Nocardioides oleivorans sp. nov., a novel crude oil-degrading bacterium. Int. J. Syst. Evol. Microbiol. 55: 1501-1504, 2005

6) Xie, C.-H. \& A. Yokota: Phylogenetic analyses of Lampropedia hyalina based on the 16S rRNA gene sequence. J. Gen. Appl. Microbiol. 49: 345-349, 2003

7) Harper, J. J. \& G. H. G. Davis: Two-dimensional thin-layer chromatography for amino acid analysis of bacterial cell walls. Int. J. Syst. Bacteriol. 29: 56-58, 1979

8) Yokota, A.: T. Tamura, T. Nishii \& T. Hasegawa: Kineococcus aurantiacus gen. nov., sp. nov., a new aerobic grampositive, motile coccus with meso-diaminopimelic acid and arabinogalactan in the cell wall. Int. J. Syst. Bacteriol. 43: 52-57, 1993

9) Yokota, A.: M. Takeuchi, T. Sakane \& N. Weiss: Proposal of six new species in the genus Aureobacterium and transfer of Flavobacterium esteraromaticum Omelianski to the genus Aureobacterium as Aureobacterium esteraromaticum comb. nov. Int. J. Syst. Bacteriol. 43: 555-564, 1993

10) Komagata, K. \& K. Suzuki: Lipid and cell-wall analysis in bacterial systematics. Methods Microbiol. 19: 161-207, 1987

11) Marmur, J.: A procedure for the isolation of deoxyribonucleic acid from microorganisms. J. Mol. Biol. 3: 208-218, 1961

12) Mesbah, M.: U. Premachandran \& W. B. Whitman: Precise measurement of the $\mathrm{G}+\mathrm{C}$ content of deoxyribonucleic acid by high-performance liquid chromatography. Int. J. Syst.
Bacteriol. 39: 159-167, 1989

13) Brosius, J.: M. L. Palmer, P. J. Kennedy \& H. F. Noller: Complete nucleotide sequence of a $16 \mathrm{~S}$ ribosomal RNA gene from Escherichia coli. Proc. Natl. Acad. Sci. U S A 75: 48014805, 1978

14) Kusukawa, N.: T. Uemori, K. Asada \& I. Kato: Rapid and reliable protocol for direct sequencing of material amplified by the polymerase chain reaction. Bio.Techniques. 9: 66-72, 1990

15) Thompson, J.: D., T. Gibson, J. F. Plewniak, F. Jeanmougin \& D. G. Higgins: The CLUSTAL X windows interface: flexible strategies for multiple sequence alignment aided by quality analysis tools. Nucleic Acids Res. 25: 4876-4882, 1997

16) Kimura, M.: A simple method for estimating evolutionary rates of base substitutions through comparative studies of nucleotide sequences. J. Mol. Evol. 16: 111-120, 1980

17) Saitou, N. \& M. Nei: The neighbor-joining method: a new method for reconstructing phylogenetic trees. Mol. Biol. Evol. 4: 406-425, 1987

18) Felsenstein, J.: Confidence limits on phylogenies: an approach using the bootstrap. Evolution. 39: 783-791, 1985

19) Kumar, S.: K. Tamura \& M. Nei: MEGA3: Integrated software for Molecular Evolutionary Genetics Analysis and sequence Alignment. Brief. Bioinform. 5: 150-163, 2004

20) Ezaki, T.: Y. Hashimoto \& E. Yabuuchi: Fluorometric deoxyribonucleic acid-deoxyribonucleic acid hybridization in microdilution wells as an alternative to membrane filter hybridization in which radioisotopes are used to determine genetic relatedness among bacterial strains. Int. J. Syst. Bacteriol. 39: 224-229, 1989

21) Lechevalier, M. P. \& H. A. Lechevalier: Chemical composition as a criterion in the classification of aerobic actinomycetes. Int. J. Syst. Bacteriol. 20: 435-443, 1970

22) Yoon, J.-H.: Y.-G. Cho, S.-T. Lee, K. Suzuki, T. Nakase \& Y.-H. Park: Nocardioides nitrophenolicus sp. nov., a $p$ nitrophenol-degrading bacterium. Int. J. Syst. Bacteriol. 49: 675-680, 1999

23) Wayne, L. G.: D. J. Brenner, R. R. Colwell, P. A. D. Grimont, O. Kandler, M. I. Krichevsky, L. H. Moore, W. E. C. Moore, R. G. E. Murray, E. Stackbrandt, M. P. Starr, H. G. Trüper: International Committee on Systematic Bacteriology. Report of the ad hoc committee on reconciliation of approaches to bacterial systematics. Int. J. Syst. Bacteriol. 37: 463-464, 1987

24) Yi, H. \& J. Chun: Nocardioides ganghwensis sp. nov., isolated from tidal flat sediment. Int. J. Syst. Evol. Microbiol. 54: 1295-1299, 2004 